\title{
Positive Influence of Intercrops on Natural Enemies in Groundnut Eco-System
}

\author{
P. Parthiban*¹, C. Chinniah ${ }^{1}$, R.K. Murali Baskaran ${ }^{2}$, K. Suresh ${ }^{1}$, A. Ravikumar ${ }^{1}$ \\ ${ }^{I}$ Department of Agricultural Entomology, Agricultural College and Research Institute, Tamil Nadu Agricultural \\ University, Madurai - 625 104, Tamil Nadu, India \\ ${ }^{2}$ National Institute of Biotic Stress Management, Raipur - 493 225, Chhattisgarh, India
}

*Corresponding Author: P. Parthiban, Department of Agricultural Entomology, Agricultural College and Research Institute, Tamil Nadu Agricultural University, Madurai - 625 104, Tamil Nadu, India

\begin{abstract}
Field experiment was carried out during 2014 to 2015 at Dryland Agricultural Research Station, Chettinad, Sivagangai district to find out cost-effective groundnut based intercropping system to enhance the activities of natural enemies viz., coccinellids and green lacewings. Groundnut (Arachis hypogaea Linnaeus; Variety: VRI II) when intercropped with maize (Zea mays L.; Variety; Co 6) and bajra (Pennisetum glaucum L.; Variety: Co 7) 4:1 ratio attracted the highest population of natural enemies like coccinellids and green lacewings, recording the population of 8.11 and 3.13 nos./10 plants and 5.94 and 2.27 nos./10 plants followed by groundnut + sorghum (Sorghum bicolor L.; Variety: Co 30), groundnut + redgram (Cajanus cajan L.; Variety: VBN (Rg) 3), groundnut + sesame (Sesamum indicum L.; Variety: Co 1), groundnut + marigold (Tagetes erecta L.; Variety: MDU 1) and groundnut + onion (Allium cepa L.; Variety: Co 1), while it was 5.94 and 2.27 nos./10 plants in groundnut pure crop.
\end{abstract}

Keywords: Arachis hypogaea, Coccinellids, Green lacewings, Intercropping system, IPM.

\section{INTRODUCTION}

Groundnut (Arachis hypogaea L.) is a leading oilseed crop in India. It is called as 'the king of oilseeds'. The seeds are rich source of edible oil (43-55\%) and protein (25-28\%), also a valuable source of vitamins viz., E, K and B (Kandakoor et al., 2014). Groundnut is native of Brazil which was introduced into India in the sixteenth century. The most important groundnut growing countries are India, China, Nigeria, Sudan and USA. It is grown over an area of 18.9 million hectares with a total production of 17.8 million tonnes in the World. However it is grown in an area of 5.5 Million hectares with a production of 9.7 Million tonnes in India, contributing about 55 per cent of the total oil seed production of the Country which ranks first in the world in terms of total area and $2^{\text {nd }}$ in production. It's cultivation is mostly confined to the Southern Indian states, viz., Gujarat, Andhra Pradesh, Karnataka, Tamil Nadu and Maharashtra accounting more than 80 per cent of the total production and acreage. The mean yield of groundnut is about $1784 \mathrm{~kg}$. of pods/ha. in Tamil Nadu, which is higher than the world average (1336 kg./ha.) and it ranks first in India. Tamil Nadu accounts for about 12 per cent ( 0.41 Million hectares) of the total area under groundnut, it contributes to 22 per cent (0.81 Million Tons) of the total production (Anonymous, 2015).

In India, about 115 insect pest species have been recorded to cause damage to groundnut at various stages including in storage. The pest incidence occurs from vegetative stage till harvest of the crop resulting in heavy crop loss and in extreme cases complete crop failure is also a common feature. Under these situations the intercropping can play a significant role to enhance the productivity and profitability per unit area and time through more efficient use of land, water and solar energy besides assuring insurance against crop failure.

In IPM, cropping system approach, particularly, use of different varieties and various intercrops are vital tools that alter population status of pests and natural enemies. Local varieties are reported to harbour lower number of pest fauna and higher number of beneficials and vice versa in case of hybrids and other high yielding varieties. Though humpty number of natural enemies are available in 
groundnut field, they are unable to check the pest population satisfactorily due to poor host searching ability. One of the important reasons being lack of chemical cues or signals from host plants and host insects. Chemical cues or kairomones emanated in the form of gas at lowest concentrations, responsible for attraction of natural enemies. Therefore, the present field experiment was undertaken to study the impact of intercropping on natural enemies in groundnut ecosystem.

\section{Materials AND Methods}

Field experiment was conducted during October 2014 to January 2015 in an area of 22 cents in a weather condition of $26 \pm 2^{\circ} \mathrm{C}$ and $73 \pm 5 \% \mathrm{RH}$ at Dryland Agricultural Research Station (DARS), Chettinad, Sivagangai District, Tamil Nadu, India. The experiment was carried out in a randomized block design (RBD) and each treatment was replicated thrice. Groundnut seeds were sown in the field at a spacing of $30 \times 10 \mathrm{~cm}$. All the standard package of practices recommended for the crops were followed except plant protection measures. Seven intercropping systems were tried as detailed below.

1. Groundnut (VRI II) + Bajra (Pennisetum glaucum L.) (Co 7)

2. Groundnut (VRI II) + Sorghum (Sorghum bicolor L.) (Co 30)

3. Groundnut (VRI II) + Maize (Zea mays L.) (Co 6)

4. Groundnut (VRI II) + Sesame (Sesamum indicum L.) (Co 1)

5. Groundnut (VRI II) + Onion (Allium cepa L.) (Co 1)

6. Groundnut (VRI II) + Marigold (Tagetes erecta L.) (MDU 1)

7. Groundnut (VRI II) + Redgram (Cajanus cajan L.) (VBN (Rg) 3)

8. Groundnut (VRI II) pure crop

The above said intercropping system was planted at 4:1 ratio with recommended spacing. Observations were recorded on population of natural enemies viz., coccinellids and green lacewings in ten randomly selected groundnut plants in each intercropping system and groundnut as pure crop, commencing from sowing to harvest of crops at ten days interval.

\section{Statistical analysis}

Data obtained from the field study were subjected to ANOVA (Analysis of Variance). In order to know the interaction between treatments, data were subject to factorial RBD analysis and the means obtained were separated by LSD (Least Significant Difference) (Gomez and Gomez, 1984).

\section{RESUlTS AND DiscusSiON}

The present study, mean population of coccinellids (Cheilomenes sexmaculatus (L.) and Coccinella transversalis Fabricius) in various intercropping systems ranged from 8.11 nos./10 plants (groundnut + maize) to 6.56 nos./10 plants (groundnut + onion) (Table 1) while it was 5.94 nos./10 plants in groundnut pure crop. The mean population of coccinellids was high (8.11 nos./10 plants) in groundnut intercropped with maize which was on par statistically like, groundnut + bajra (7.39 nos./10 plants), followed by groundnut + sorghum intercropping system $(7.11$ nos./10 plants), which was on par statistically like groundnut + redgram $(7.00$ nos./10 plants $)$, groundnut + marigold $(6.83$ nos./10 plants) and groundnut + sesame (6.83 nos./10 plants). Groundnut intercropped with onion recorded the coccinellid population of 6.56 nos./10 plants, while it was 5.94 nos./10 plants in groundnut pure crop.

Groundnut intercropped with bajra (4:1) recorded the highest mean population of $C$. zastrowi sillemi (3.67 nos./10 plants), followed by groundnut + marigold (3.20 nos./10 plants) which was on par with groundnut intercropped with sorghum (3.20 nos./10 plants), maize (3.13 nos./10 plants) and redgram (3.13 nos./10 plants) (Table 2). The C. zastrowi sillemi mean population of 3.00 and 2.87 nos./10 pants were recorded in groundnut intercropped with sesame and onion, respectively, while it was 2.27 nos./10 plants in groundnut pure crop. There is no significant difference among intercropping systems on 40 DAS, while on 50, 60, 70 and 80 DAS similar trend was noticed like mean population of $C$. zastrowi sillemi in various intercropping system.

Pest outbreaks are rare in polyculture condition due to the ability of the diverse plant culture to selfsustain through natural pest control by increasing the occurrence of natural enemies (Scherr and 
McNeely, 2008). Polyculture offers alternate prey or hosts and alternate food sources such as pollen and nectar (Root, 1973). Polycultures that support high densities of natural enemies might have increased incidence of predation and parasitization of herbivores (Altieri and Letourneau, 1982).

Table 1. Population of Coccinellids in groundnut based intercropping system (Season: Rabi 2014)

\begin{tabular}{|c|c|c|c|c|c|c|c|}
\hline \multirow{2}{*}{ Treatments } & \multicolumn{6}{|c|}{ Population of Coccinellids (Nos. / 10 plants) ( $^{* *}$} & \multirow{2}{*}{ Mean } \\
\hline & 30 DAS $^{* * *}$ & 40 DAS & 50 DAS & 60 DAS & 70 DAS & 80 DAS & \\
\hline Groundnut + Bajra & $\begin{array}{c}3.33 \\
(1.82) \\
\end{array}$ & $\begin{array}{c}5.00 \\
(2.24)^{\mathrm{ab}} \\
\end{array}$ & $\begin{array}{c}6.67 \\
(2.58)^{\mathrm{bc}} \\
\end{array}$ & $\begin{array}{c}9.00 \\
(3.00)^{\mathrm{ab}} \\
\end{array}$ & $\begin{array}{l}10.33 \\
(3.21)^{\mathrm{b}} \\
\end{array}$ & $\begin{array}{l}10.00 \\
(3.16)^{\mathrm{bc}}\end{array}$ & $\begin{array}{c}7.39 \\
(2.72)^{\mathrm{a}} \\
\end{array}$ \\
\hline $\begin{array}{l}\text { Groundnut + } \\
\text { Sorghum }\end{array}$ & $\begin{array}{c}3.00 \\
(1.73) \\
\end{array}$ & $\begin{array}{c}4.67 \\
(2.16)^{\mathrm{bc}}\end{array}$ & $\begin{array}{c}7.33 \\
(2.71)^{\mathrm{ab}} \\
\end{array}$ & $\begin{array}{l}8.67 \\
(2.94)^{\mathrm{bc}} \\
\end{array}$ & $\begin{array}{c}9.67 \\
(3.11)^{\mathrm{bc}}\end{array}$ & $\begin{array}{c}9.33 \\
(3.05)^{\mathrm{cd}} \\
\end{array}$ & $\begin{array}{c}7.11 \\
(2.67)^{\mathrm{b}}\end{array}$ \\
\hline Groundnut + Maize & $\begin{array}{c}3.33 \\
(1.82) \\
\end{array}$ & $\begin{array}{c}5.67 \\
(2.38)^{\mathrm{a}} \\
\end{array}$ & $\begin{array}{c}7.67 \\
(2.77)^{\mathrm{a}} \\
\end{array}$ & $\begin{array}{c}9.67 \\
(3.11)^{\mathrm{a}} \\
\end{array}$ & $\begin{array}{c}11.33 \\
(3.37)^{\mathrm{a}} \\
\end{array}$ & $\begin{array}{c}11.00 \\
(3.32)^{\mathrm{a}} \\
\end{array}$ & $\begin{array}{c}8.11 \\
(2.85)^{\mathrm{a}} \\
\end{array}$ \\
\hline Groundnut + Sesame & $\begin{array}{c}3.33 \\
(1.82) \\
\end{array}$ & $\begin{array}{c}5.00 \\
(2.24)^{\mathrm{ab}} \\
\end{array}$ & $\begin{array}{c}7.00 \\
(2.65)^{\mathrm{abc}} \\
\end{array}$ & $\begin{array}{c}8.00 \\
(2.83)^{\mathrm{cd}} \\
\end{array}$ & $\begin{array}{c}9.33 \\
(3.05)^{\mathrm{c}} \\
\end{array}$ & $\begin{array}{c}8.33 \\
(2.89)^{\mathrm{ef}} \\
\end{array}$ & $\begin{array}{c}6.83 \\
(2.61)^{\mathrm{b}} \\
\end{array}$ \\
\hline Groundnut + Onion & $\begin{array}{c}2.67 \\
(1.63) \\
\end{array}$ & $\begin{array}{c}4.33 \\
(2.08)^{\mathrm{bc}} \\
\end{array}$ & $\begin{array}{c}6.67 \\
(2.58)^{\mathrm{bc}}\end{array}$ & $\begin{array}{c}7.67 \\
(2.77)^{\mathrm{d}} \\
\end{array}$ & $\begin{array}{c}9.33 \\
(3.05)^{\mathrm{c}} \\
\end{array}$ & $\begin{array}{c}8.67 \\
(2.94)^{\mathrm{de}} \\
\end{array}$ & $\begin{array}{l}6.56 \\
(2.56)^{\mathrm{bc}}\end{array}$ \\
\hline $\begin{array}{c}\text { Groundnut + } \\
\text { Marigold }\end{array}$ & $\begin{array}{c}2.67 \\
(1.63) \\
\end{array}$ & $\begin{array}{c}4.67 \\
(2.16)^{\mathrm{bc}} \\
\end{array}$ & $\begin{array}{c}6.33 \\
(2.52)^{\mathrm{c}} \\
\end{array}$ & $\begin{array}{c}8.00 \\
(2.83)^{\mathrm{cd}} \\
\end{array}$ & $\begin{array}{l}10.00 \\
(3.16)^{\mathrm{bc}}\end{array}$ & $\begin{array}{c}9.33 \\
(3.05)^{\mathrm{cd}} \\
\end{array}$ & $\begin{array}{c}6.83 \\
(2.61)^{\mathrm{b}} \\
\end{array}$ \\
\hline $\begin{array}{l}\text { Groundnut + } \\
\text { Redgram }\end{array}$ & $\begin{array}{c}3.00 \\
(1.73)\end{array}$ & $\begin{array}{c}4.33 \\
(2.08)^{\mathrm{bc}}\end{array}$ & $\begin{array}{l}6.67 \\
(2.83)^{\mathrm{bc}}\end{array}$ & $\begin{array}{c}7.67 \\
(2.77)^{\mathrm{d}} \\
\end{array}$ & $\begin{array}{l}10.00 \\
(3.16)^{\mathrm{bc}}\end{array}$ & $\begin{array}{c}10.33 \\
(3.21)^{\mathrm{ab}} \\
\end{array}$ & $\begin{array}{c}7.00 \\
(2.65)^{\mathrm{b}}\end{array}$ \\
\hline Groundnut pure crop & $\begin{array}{c}3.00 \\
(1.73) \\
\end{array}$ & $\begin{array}{c}4.00 \\
(2.00)^{\mathrm{c}} \\
\end{array}$ & $\begin{array}{c}6.33 \\
(2.58)^{\mathrm{c}} \\
\end{array}$ & $\begin{array}{c}7.33 \\
(2.71)^{\mathrm{d}} \\
\end{array}$ & $\begin{array}{c}7.33 \\
(2.71)^{d} \\
\end{array}$ & $\begin{array}{c}7.67 \\
(2.77)^{\mathrm{f}} \\
\end{array}$ & $\begin{array}{c}5.94 \\
(2.44)^{\mathrm{d}} \\
\end{array}$ \\
\hline SEd & NS* & 0.0907 & 0.0751 & 0.0681 & 0.0632 & 0.0640 & 0.0741 \\
\hline $\mathrm{CD}(\mathrm{P}=\mathbf{0 . 0 5})$ & NS & 0.1945 & 0.1611 & 0.1460 & 0.1355 & 0.1373 & 0.1590 \\
\hline
\end{tabular}

*NS: Non significant; **Each value is the mean of three replications

***DAS: Days after sowing

Figures in parentheses are square root transformed values

In a column, means followed by common letter(s) are not significantly different by LSD $(\mathrm{P}=0.05)$

Table 2. Population of Chrysoperla zastrowi sillemi (Esben-Peterson) in groundnut based intercropping system (Season: Rabi 2014)

\begin{tabular}{|l|c|c|c|c|c|c|}
\hline \multirow{2}{*}{ Treatments } & \multicolumn{5}{|c|}{ Population of C. zastrowi sillemi (Nos. / 10 plants)** $^{*}$} & \multirow{2}{*}{ Mean } \\
\cline { 2 - 6 } & $\mathbf{4 0}$ DAS*** & $\mathbf{5 0}$ DAS & $\mathbf{6 0}$ DAS & 70 DAS & 80 DAS & \\
\hline \multirow{2}{*}{ Groundnut + Bajra } & 2.67 & 3.33 & 4.00 & 4.33 & 4.00 & 3.67 \\
& $(1.63)$ & $(1.82)^{\mathrm{a}}$ & $(2.00)^{\mathrm{a}}$ & $(2.08)^{\mathrm{a}}$ & $(2.00)^{\mathrm{ab}}$ & $(1.92)^{\mathrm{a}}$ \\
\hline \multirow{2}{*}{ Groundnut + Sorghum } & 2.00 & 2.67 & 3.67 & 4.00 & 3.33 & 3.13 \\
& $(1.41)$ & $(1.63)^{\mathrm{bc}}$ & $(1.92)^{\mathrm{ab}}$ & $(2.00)^{\mathrm{ab}}$ & $(1.82)^{\mathrm{bcd}}$ & $(1.77)^{\mathrm{b}}$ \\
\hline \multirow{2}{*}{ Groundnut + Maize } & 1.67 & 3.00 & 3.33 & 4.00 & 3.67 & 3.13 \\
& $(1.29)$ & $(1.73)^{\mathrm{ab}}$ & $(1.82)^{\mathrm{ab}}$ & $(2.00)^{\mathrm{ab}}$ & $(1.92)^{\mathrm{abc}}$ & $(1.77)^{\mathrm{b}}$ \\
\hline \multirow{2}{*}{ Groundnut + Sesame } & 2.33 & 3.00 & 3.33 & 3.33 & 3.00 & 3.00 \\
& $(1.53)$ & $(1.73)^{\mathrm{ab}}$ & $(1.82)^{\mathrm{ab}}$ & $(1.82)^{\mathrm{bc}}$ & $(1.73)^{\mathrm{cd}}$ & $(1.73)^{\mathrm{bc}}$ \\
\hline \multirow{2}{*}{ Groundnut + Onion } & 2.00 & 2.67 & 3.00 & 3.33 & 3.33 & 2.87 \\
& $(1.41)$ & $(1.63)^{\mathrm{bc}}$ & $(1.73)^{\mathrm{bc}}$ & $(1.82)^{\mathrm{bc}}$ & $(1.82)^{\mathrm{bcd}}$ & $(1.69)^{\mathrm{c}}$ \\
\hline \multirow{2}{*}{ Groundnut + Marigold } & 2.67 & 3.00 & 3.00 & 4.00 & 3.33 & 3.20 \\
& $(1.63)$ & $(1.73)^{\mathrm{ab}}$ & $(1.73)^{\mathrm{bc}}$ & $(2.00)^{\mathrm{ab}}$ & $(1.82)^{\mathrm{bcd}}$ & $(1.79)^{\mathrm{b}}$ \\
\hline \multirow{2}{*}{ Groundnut + Redgram } & 1.67 & 2.67 & 3.00 & 4.00 & 4.33 & 3.13 \\
& $(1.29)$ & $(1.63)^{\mathrm{bc}}$ & $(1.73)^{\mathrm{bc}}$ & $(2.00)^{\mathrm{ab}}$ & $(2.08)^{\mathrm{a}}$ & $(1.77)^{\mathrm{b}}$ \\
\hline \multirow{2}{*}{ Groundnut pure crop } & 1.67 & 2.00 & 2.33 & 2.67 & 2.67 & 2.27 \\
& $(1.29)$ & $(1.41)^{\mathrm{c}}$ & $(1.53) \mathrm{c}$ & $(1.63)^{\mathrm{c}}$ & $(1.63)^{\mathrm{d}}$ & $(1.51)^{\mathrm{d}}$ \\
\hline SEd & $\mathrm{NS}$ & 0.1214 & 0.1100 & 0.1027 & 0.1062 & 0.1145 \\
\hline CD (P=0.05) & $\mathrm{NS}$ & 0.2205 & 0.2360 & 0.2203 & 0.2278 & 0.2456 \\
\hline
\end{tabular}

*NS: Non significant

**Each value is the mean of three replications

***DAS: Days after sowing

Figures in parentheses are square root transformed values

In a column, means followed by common letter(s) are not significantly different by LSD $(\mathrm{P}=0.05)$

The present results are in agreement with the findings of other workers who have reported that intercropping maize, sorghum or cowpea in cotton increased the population of arthropod predators in the main crop (Rajput and Daware, 2002). Colonization of natural enemies was reported in many 
intercropping systems including cotton + sunflower (Swaminathan et al., 1999), cotton + safflower (Li, 1987), maize + cabbage (Wu et al., 1991), cotton + alfalfa (Godfrey and Fleigh, 1994) etc., an augmentative biological control. The migratory nature of ladybird beetles was shown by Lin et al. (2003) in China when cotton intercropped with alfalfa which attracted greater number of ladybird beetles, lacewings and spiders, when alfalfa was cut to force migration of natural enemies to cotton. Hanumantharaya et al. (2008) also found that intercrop of lucrene @ 1:1 ratio increased the effectiveness of green lacewings.

Kranthi and Russell (2009) in their review of changing trends in cotton pest management have mentioned about the lady beetles and lacewings as important predators in cotton intercropped with pulse crops. Mensah (1999) quantified that 2.1, 2.5 and 1.2 times abundance of predatory beetles, bugs, lacewings and spiders per meter row in intercropped cotton compared to monocultures.

A rich diversity in predatory insect and parasitoid species was recorded from intercropping system like groundnut + maize and groundnut + bajra wherein intercrop supplied pollen and nectar as supplementary feed to the natural enemies (Bianchi et al., 2006). This supplementary food resource increases the parasitoid fecundity, longevity (Tylianakis et al., 2004) and also favours rapid colonization of generalist predators (Symondson et al., 2002). The dense vegetation created by the presence of eggplant with intercrop and border crop had led to rapid colonization and occurrence of natural enemies in higher densities. This is in accordance with the findings of Sprenkel et al. (1979) and Horn (1981). Similarly, Letourneau and Altieri (1983) and Letourneau (1990) also suggested that predator colonization rates could be manipulated through vegetational diversification of the crop habitat.

Natural enemies harboured by maize consist primarily of ants, spiders, rove beetles, predaceous mites, and ground beetles (Rose and Dively, 2007). Similar report of intercrops increasing natural enemy diversity was reported by Singh et al. (1991). They found that sorghum as an intercrop significantly increased the natural enemies like Laius mallifera, $C$. septempunctata, Orius $\mathrm{sp}$. and $C$. sexmaculata which controlled thrips incidence in groundnut. Baskaran et al. (1993) reported that growing intercrops such as cowpea and pearl millet reduced pest damage and favoured the abundance of natural enemies in groundnut ecosystem. Kennedy et al. (1997) noticed that intercropping groundnut with pearl millet favoured the predators and parasites of groundnut insect pests. Duffield and Reddy (1997) reported an increased activity of coccinellids and spiders in leguminous intercrops.

Surulivelu (2004) reported that cowpea was a short-duration pulse crop which attracted aphids, thus increasing occurrence of coccinellids and multiplication of coccinellids and other predators in groundnut ecosystem. Coccinellids were significantly abundant in pigeonpea with sorghum or greengram or groundnut systems (Srinivasa Rao, 2007). Singh et al. (1991) studied the influence of intercropping on natural enemy complex in groundnut and reported that the population of spiders was higher in intercropping system than that of sole crop. Wu et al. (1991) reported that intercropping maize in cotton fields increased the population of Spiders, Coccinellids and Chrysopids by 62.8$115.7 \%$ compared to control fields. Mahabaleshwar et al. (2003) noticed that average population of $C$. carnea and spiders were significantly high on cotton intercropped with lucerne, cowpea, and groundnut. Gavarra and Raros (1975) found more predatory spiders and coccinellids in groundnut and maize intercropping system than in sole crop of groundnut.

In a study involving intercropping systems in cotton Hegde et al. (2003) recorded similar observations in cotton intercropped with sorghum. Andow and Risch (1987) also established the fact that poly cultures of maize / bean / squash and maize / clove improved parasitism rates of T. minutum by 1.9 times over monocultures of crop. Up to $30 \%$ crop pest reduction due to "natural enemy effect" have been observed by Baliddawa, 1985 in intercropped systems. In addition to natural enemy effects, the groundnut component crop as non-host plants could have further constituted a physical barrier to stem borer pests in pearl millet that possibly inhibited their inter or intra row migration in intercropped systems (Chabiolaye et al., 2005; Manjula and Prasanna Lakshmi, 2014; Sujayanand et al., 2015).

\section{REFERENCES}

Andow, D.A. and S.J. Risch (1987). Parasitism in diversified agro ecosystems: Phenlogy of Trichogramma minutum (Hymenoptera:Trichogrammatidae). Entomophaga. 32: 255-260.

Anonymous. 2015. Economic Survey 2014-15, Government of India. 33 p. 
Altieri, M.A. and D.K. Letourneau (1982). Vegetation management and biological control in agroecosystems. Food Products Press, New York. 261 p.

Baliddawa, C.W. (1985). Plant Species Diversity and Crop Pest Control-An analytical review. Insect Sci. Its Appli. 6: 479-487.

Bianchi, F.J.J.A., C.J.H. Booij and T. Tscharntke (2006). Sustainable pest regulation in agricultural landscapes: a review on landscape composition, biodiversity and natural pest control. Proceedings of the Royal Society. 273: 1715-1727.

Baskaran, R.K.M., J. Chandrasekharan and S. Thangavelu (1993). Effect of intercrop on the incidence of groundnut leafminer. Madras Agric. J. 80 (1): 11-13.

Chabiolaye, A., C. Nolte, F. Schulthess and C. Borgemeister (2005). Relationships of intercropped maize stem borer damage to maize yield and land use efficiency in the humid forest of Cameroon. Bulletin Entomological Res. 95: 417-427.

Duffield, S.J and Y.V. Reddy (1997). Distribution and increment of predators of Helicoverpa armigera in intercropped sorghum and short duration pigeonpea. Crop Research. 14: 315- 335.

Godfrey, L.D. and T.F. Fleigh (1994). Alfalfa harvest strategy effect on lygus bug (Hemiptera: Miridae) and insect predator population density implication for use as trap crop in cotton. Environ. Entomol. 23 (5): 1102-1118.

Gavarra, M.R and R.S. Raros (1975). Crop - crop diversity as a key component of IPM - A review. Philippines Ent. 2: 427-444.

Gomez, K.A. and A.A. Gomez (1984). Statistical procedures for agricultural research. $2^{\text {nd }}$ ed. John Wiley and Sons, New York. 657 p.

Hegde, M., K.A. Kulkarni and S. Lingappa (2003). Impact of intercrops on conservation of Chrysperla carnea (Stephens) and other natural enemies in cotton ecosystems. Indian J. Plant Prot. 31: 98-104.

Hanumantharaya, L., K. Basavannagoud and L. Krishnanaik (2008). Use of green lacewing, Chrysoperla carnea (Stephens) and neem seed kernel extract for management of insect pests of cotton. Kar. J. Agric. Sci. 21 (1): 41-44.

Horn, D. J. (1981). Effect of weedy backgrounds on colonization of collards by green peach aphid, Myzus persicae, and its major predators. Environ. Entomol. 10: 285-289.

Kennedy, F.J.S., R. Balaguranathan, A. Christopher and K. Rajamanickam (1997). Insect pest management in peanut: a cropping system approach. Tropical Agric. 71 (2): 116-118.

Kandakoor, S.B, H.K. Khan, A.K. Chakravarthy, C.T. Ashok Kumar and P. Venkataravana (2014). Biochemical constituents influencing thrips resistance in groundnut germplasam. J. Environ. Biol. 35: 675-681.

Kranthi, K. R. and D. A. Russell (2009). Changing trends in cotton pest management. Integrated Pest Management: Innovative development process: 499-541.

Li, H.C. (1987). Augmentation of Chrysopa sp. to control cotton aphids by intercropping cotton and safflower. Chinese J. Biol. Control. 3: 109-111.

Lin, R., H. Liang, R. Zhang, C. Tian and Y. Ma (2003). Impact of alfalfa / cotton intercropping and management on some aphid predators in China. J. Appl. Entomol. 127 (1): 33-36.

Letourneau, D.K. and M.A. Altieri (1983). Abundance patterns of a predator, Orius tristicolor (Hemiptera Anthrocoridae), and its prey, Frankliniella occidentalis (Thysanoptera: Thripidae): habitat attraction in polycultures versus monocultures. Environ. Entomol. 12: 1464-1469.

Letourneau, D.K. (1990). Code of ant-plant mutualism broken by parasite. Science. 248: 215-217.

Mensah, K.R. (1999). Habitat diversity: Implications for the conservation and use of predatory insects of Helicoverpa spp. in cotton eco-systems in Australia. Int. J. Pest Manag. 45: 91-100.

Mahabaleshwar, H., K.A. Kulkarni and S. Lingappa (2003). Impact of intercrops on conservation of Chrysoperla carnea (Stephens) and other natural enemies in cotton ecosystem. Indian J. Plant Protec. 31 (1): 98-104.

Manjula, K and R. Prasanna Lakshmi (2014). Positive influence of intercrops on coccinellid and spider fauna in groundnut. International J. Plant, Animal and Environ. Sci. 4 (4): 207-211.

Rajput, K.P. and D.G. Daware (2002). Effect of different intercrops on the population build-up of Chrysoperla and coccinellids on cotton. J. Cotton Res. and Devt. 16: 106-107.

Root, R. (1973). Organisation of a plant-arthropod association in simple and diverse habitats. The fauna of collards (Brassica oleracea L.). Ecol. Monogr. 43: 93-124.

Rose, R.I. and G.P. Dively (2007). Effects of insecticide-treated and lepidopteran-active $B t$ transgenic sweet corn on the abundance and diversity of arthropods. Environ. Entomol. 36 (5): 1254-1268. 
Sujayanand, G.K., R.K. Sharma, K. Shankarganesh, Supradip Saha and R.S. Tomar (2015). Crop Diversification for Sustainable Insect Pest Management in Eggplant. Florida Entomologist. 98 (1): 305-314.

Surulivelu, T. (2004). Pest Control in Organic Cotton. Research Notes. Available online, www.cicr.org.in.

Scherr, S.J. and J.A. McNeely (2008). Biodiversity conservation and agricultural sustainability: Towards a new paradigm of 'ecoagriculture' landscapes. Philosophical Transactions of the Royal Society. USA. $477 \mathrm{p}$.

Singh T.V.K., K.M. Singh and R.N. Singh (1991). Influence of intercropping: III. Natural enemy complex in groundnut. Indian J. Entomol. 53: 63-68.

Swaminathan, V.R., R.K. Murali Baskaran and N.R. Mahadevan (1999). Influence of intercropping on the conservation of Chrysoperla caranea (Stephens) in cotton. J. Biol. Control 13: 111-114.

Sprenkel, R.K., W.M. Brooks, J.W. Duyn and L.L. Deitz (1979). The effect of three cultural variables on the incidence of Nomuraea rileyi, phytophagous lepidoptera, and their predators on soybeans. Environ. Entomol. 8: 334-339.

Symondson, W.O.C., K.D. Sunderland and M.H. Greenstone (2002). Can generalist predators be effective biocontrol agents. Ann. Review Entomol. 47: 561-94.

Srinivasa Rao, M. (2007). Paper on "organic farming in rainfed agriculture" held at CRIDA, 1-21 November.

Tylianakis, J.M., R.K. Didham and S.D. Wratten (2004). Improved fitness of aphid parasitoids receiving resource subsidies. Ecology. 85: 658-666.

Wu, G., Z. Chen, M. Ji, S. Dong, H. Li, J. An and J. Shi (1991). Influence of interplanting corn in cotton fields on natural enemy populations and its effect on pest control in southern Shaanxi [Chinese]. Chinese J. Biol. Con. 7 (3): 101-104.

Citation: P. Parthiban et al., "Positive Influence of Intercrops on Natural Enemies in Groundnut Eco-System ", International Journal of Research Studies in Zoology, vol. 4, no. 2, p. 1-6, 2018. http://dx.doi.org/10.20431/ 2454-941X.0402001

Copyright: (c) 2018 Authors. This is an open-access article distributed under the terms of the Creative Commons Attribution License, which permits unrestricted use, distribution, and reproduction in any medium, provided the original author and source are credited. 